\title{
JOINT DEVELOPMENT OF MINERAL RESOURCES - AN ASIAN SOLUTION?
}

\section{Yu Hui*}

\section{INTRODUCTION}

With recognition of the petroleum potential of submarine areas, the consequent development of offshore oil industries, and the extension of coastal state jurisdiction over marine resources up to 200 nautical miles and beyond, many continental shelves bearing oil and gas have become subject to overlapping or concurrent claims by the opposite and adjacent coastal States. Such situations have given rise to both ocean boundary delimitation problems and oil exploration and exploitation problems, inviting the concern of the international community not only regarding the commercial and political aspects of those problems, but also their academic or conceptual aspects.

In recent years there has been a substantial increase in State practice favouring regimes for the joint development of such areas. The first example related to joint development in connection with offshore delimitation is the Agreement concerning the Delimitation of the Continental Shelf in the Persian Gulf between the Shaykhdom of Bahrain and the Kingdom of Saudi Arabia of $1958^{1}$. The two Governments agreed, while dividing the continental shelf in the Persian Gulf between them, to develop the oil resources of a defined hexagonal area under Saudi Arabia's jurisdiction in the manner determined by Saudi Arabia, but to share equally in the income from the exploitation of those resources ${ }^{2}$. Although this agree-

\footnotetext{
- Legal Officer, State Oceanic Asministration, Ocean Management Department, Treaty and Law Division, Beijing; Ph.D.Cand., University of Amsterdam.

1. Agreement concerning the Delimitation of the Continental Shelf in the Persian Gulf between the Shaykhdom of Bahrain and the Kingdom of Saudi Arabia, 22 February 1958, in: R. CHURCHILL, M. NORDQUIST and S. HOUSTON LAY, New Directions in the Law of the Sea, Vol. 5 (Oceana Publications, 1977) pp. 207-211.
}

2. Ibid., Art. 2.

Ko Swan Sik et al. (eds.), Asian Yearbook of International Law, Volume 2, 87-112 (c) 1994 Kluwer Academic Publishers. Printed in the Netherlands 
ment does not establish a joint regime, it finds a way to resolve together both boundary delimitation and oil exploitation problems.

The first agreement on co-operation for joint development was concluded with respect to resources extending across a land boundary: the Agreement between Czechoslovakia and Austria concerning the Working of Common Deposits of Natural Gas and Petroleum concluded in $1960^{3}$. This agreement recognizes the utility and necessity of co-operation and co-ordination in the working of a natural gas deposit on the VysokáZwerndorf frontier and similar common deposits, and stipulates that the Contracting Parties shall work their proportionate shares of the total reserves in each individual common deposit to ensure that each party receives a share of total production in proportion to the amount of reserves in its territory ${ }^{4}$. In 1962, following the discovery of huge deposits of natural gas and oil in the Ems Estuary, the Netherlands and the Federal Republic of Germany concluded a Supplementary Agreement to the Ems-Dollard Treaty signed by the two States in $1960^{5}$. The Supplementary Agreement leaves the boundary question unresolved, and calls on the Parties to "co-operate in a spirit of good-neighbourliness with respect to all questions arising in connection with prospecting for and the extraction of natural resources" 6 . According to the agreement, German and Netherlands concessionaires are entitled to an equal share of the petroleum and natural gas obtained in the course of their extraction in a clearly delimited zone. ${ }^{7}$ Although the latter agreement only relates to an estuary area, it was referred to by the International Court of Justice in the 1969 North Sea Continental Shelf Cases $^{8}$ and opened the way for application of the idea of joint development in respect of overlapping claims to continental shelf areas. In 1965, Great Britain and Norway concluded an agreement on the delimitation of their continental shelf ${ }^{9}$, in which they included a "common resource clause" in order to provide for co-opera-

3. Agreement between the Government of the Czechoslovak Republic and the Austrian Federal Republic concerning the Working of Common Deposits of Natural Gas and Petroleurn, 23 January 1960, 495 UNTS pp. 134-140.

4. Ibid., Preamble, and Arts. 1 and 5 para. 1; see also R. LAGONI, "Oil and Gas Deposits Across National Frontiers", 73 AJIL (1979) pp. 222-223.

5. Treaty between the Kingdom of the Netherlands and the Federal Republic of Germany concerning Arrangements for Co-operation in the Ems Estuary (Ems-Dollard Treaty), 8 April 1960,509 UNTS P. 64; Supplementary Agreement to the Treaty concerning Arrangements for Co-operation in the Ems Estuary, 14 May 1962, 509 UNTS p. 140. A new treaty concerning the Ems-Dollard region was signed in 1984: Treaty between the Kingdom of the Netherlands and the Federal Republic of Germany concerning Co-operation in the Area of the Ems and Dollard as well as in the Adjacent Region, 10 September 1984, Tractatenblad (Netherlands Treaty Series) 1984 No. 118 .

6. Supplementary Agreement supra n. 5.

7. Ibid., Art. 5 para. 1.

8. [1969] ICJ Rep. para. 97; reprinted in 8 ILM (1969) p. 382. 
tion in case a transboundary deposit of fluid minerals were discovered in the future. Since then, this clause has become a kind of standard formula for many obligations on co-operation under such agreements. In the 1969 North Sea Continental Shelf Cases, the International Court of Justice referred to the idea of "joint exploitation":

"In a sea with the particular configuration of the North Sea, and in view of the particular geographical situation of the Parties' coastline upon that sea, the methods chosen by them for the purpose of fixing the delimitation of their respective areas may happen in certain localities to lead to an overlapping of the areas appertaining to them. The Court considers that such a situation must be accepted as a given fact and resolved either by an agreed, or failing that by an equal division of the overlapping areas, or by agreements for joint exploitation, the latter solution appearing particularly appropriate when it is a question of preserving the unity of a deposit" ${ }^{\prime 10}$.

Judge Jessup further emphasized in his separate opinion that,

"as the Court states, the principle of joint exploitation is particularly appropriate in cases involving the principle of the unity of a deposit, it may have a wider application in agreements reached by the parties concerning the still undelimited but partially overlapping areas of the continental shelf which have been in dispute"11.

Joint exploitation was also favoured in the Tunisia and Libya Continental Shelf Case. Judge Evensen concluded in his separate opinion that:

"It seems advisable that the Parties in the present case...should include provisions on unitization in cases where a petroleum field is situated on both sides of the dividing line or the dividing line for the above proposed zone of joint exploitation"12.

The signing (11 December 1989) of a Treaty on the Zone of Co-operation in the Timor Sea between Indonesia and Australia ${ }^{13}$ serves to highlight the current interest of the international community in joint development regimes, and to demonstrate the acceptability and viability of such regimes.

9. Agreement between the Government of the United Kingdom of Great Britain and Northern Ireland and the Government of the Kingdom of Norway relating to the Delimitation of the Continental Shelf between the Two Countries, 10 March 1965, 551 UNTS p. 214.

10. [1969] ICJ Rep. para. 99; ILM supra n. 8, p. 383.

11. Separate Opinion of Judge JESSUP, ibid., p. 392.

12. [1982] ICJ Rep. pp. 322-323; reprinted in 21 ILM (1982) p. 317.

13. Australia-Indonesia: Treaty on the Zone of Co-operation in an Area between the Indonesian Province of East Timor and Northern Australia, 11 December 1989, 29 ILM (1990) pp. 469537. 
The very idea of joint development implies the willingness of States to work together in a spirit of co-operation, and to co-ordinate their activities. Since the Truman Proclamation of 1945, the continental shelf has been regarded as an important part of State territory. For a State to put aside boundary delimitation issues, and instead place a part of its continental shelf under an arrangement for joint exploitation with a neighbouring State or States, involves a decision to abstain from exercising, fully or partially, the exclusive sovereignty to which it is entitled. This raises issues of extreme political sensitivity which can be resolved only after careful appraisal of the political, economic, scientific or other benefits perceived, and consideration of available alternatives.

Many considerations could motivate a State in its choice of co-operation through joint development over unilateral exploitation of a resource: (I) The physical and geological properties of the resource (say petroleum and natural gas) may be such that unilateral exploitation could adversely affect the physical condition of the deposit in the overlapping area. It may impair, and under certain geological conditions even destroy, the possibility to exploit a part of the deposit. In such a situation, joint development can prevent the infringement of the interests of one of the States concerned. (2) From the technical point of view, joint development arrangements provide the possibility of increasing efficiency and productivity by reducing costs, while at the same time facilitating transfer of technology. (3) Economic factors, including a State's urgent need for oil and gas, would move a government to seek a solution that could provide early benefits from development rather than let the resource remain unutilized while negotiations over boundaries which have the potential to sour relations between the parties, drag on. (4) From the legal and political points of view, States may see in a joint development arrangement the means of laying aside sovereignty issues without actually abandoning their claims to sovereign control and administration over such activities. As one authority observes,

"Perhaps the strongest reason for State's opting for a joint undertaking would be its sense of urgency or obligation to protect its interests in oil and gas deposits combined with a desire to maintain or cement good relations with the other State"14.

The purposes of this study are to note the common features of existing joint development arrangements by analyzing State practice in the field; to discuss the legal issues arising in context of joint development in light of relevant provisions of the 1982 United Nations Convention on the Law

14. M. J. VALENCIA et al., 'Southeast Asian Seas: Joint Development of Hydrocarbons in Overlapping Claim Area?', 16 Ocean Development and International Law (1986) p. 223. 
of the Sea; and to explore China's policy with respect to joint development of its marine areas.

\section{OVERVIEW OF STATE PRACTICE}

For the purpose of this study, "joint development" is a regime which has the following features: First, by definition, "joint" development is opposed to "individual" or "unilateral" development, e.g. development under the exclusive sovereignty of a single State. Second, joint development arrangements generally relate to exploration and exploitation of transboundary or "straddling" deposits or fields of mineral resources in the sub-soil of a geographically defined area, often a continental shelf or exclusive economic zone, i.e. deposits or fields that lie across and on either side of a potential territorial boundary. Third, joint development regimes are based on inter-governmental agreements. Fourth, there have been in practice two types of joint development arrangements: (a) joint development pending delimitation, and $(b)$ joint development with the boundary delimited. The following published agreements concerning joint development of a resource, listed chronologically, seem to indicate increasing recognition by States of the efficacy and viability of the concept.

(1) Agreement concerning the Delimitation of the Continental Shelf in the Persian Gulf between the Shaykhdom of Bahrain and the Kingdom of Saudi Arabia, dated 22 February $1958^{15}$. The agreement provides that the oil resources in the Fasht bu Saafa Hexagon, which is under Saudi Arabian jurisdiction, are to be developed in the manner determined by Saudi Arabia on condition that it gives the Government of Bahrain half of the net income derived from this development. The arrangement is not to impair the rights of sovereignty and administration of the Saudi Arabian Government in the area ${ }^{16}$.

(2) Agreement between the Government of the Czechoslovak Republic and the Austrian Federal Government concerning the Working of Common Deposits of Natural Gas and Petroleum, dated 23 January $1960^{17}$. This Agreement is designed to promote co-operation and co-ordination for the development of a "common" deposit of natural gas on both sides of the boundary in the Vysoka-Zwerndorf frontier area so that each party may

15. See supra n. 1.

16. Ibid.

17. See supra n. 3. 
receive a share of the total production in proportion to the amount of reserves in its territory ${ }^{18}$.

(3) Supplementary Agreement to the Treaty concerning Arrangement for Co-operation in the Ems Estuary (Ems-Dollard Treaty) between the Netherlands and the Federal Republic of Germany, dated 14 May $1962^{19}$. The Agreement establishes a resource exploitation area partitioned by a boundary line, and provides that each party shall exercise its jurisdiction and carry out prospecting and extraction on its side of the line, but would be entitled to an equal share of the petroleum and natural gas extracted, expenses also being shared in the same proportion ${ }^{20}$.

(4) Agreement between the State of Kuwait and the Kingdom of Saudi Arabia relating to Partition of the Neutral Zone, dated 7 July $1965^{21}$. Under this Agreement, the "Neutral Zone" established by the Aqeer [Al Uqair] Agreement of 1922 between Kuwait and Saudi Arabia in which the two States had equal rights ${ }^{22}$, was partitioned by a boundary line into two equal parts, annexed respectively to each State "as an integral part of its territory". Each State is to exercise over that part of the partitioned Neutral Zone identical rights of administration, legislation and defence, and to respect the rights of the other Party to the shared natural resources in that part of the partitioned zone annexed to its territory ${ }^{23}$. The Agreement goes on to provide that "the two Contracting Parties shall exercise their equal rights in the submerged area beyond the aforesaid six mile limit...by means of joint exploitation, unless the two Parties agree otherwise" 24 .

(5) Agreement on Settlement of Maritime Boundary Lines and Sovereign Rights over Islands between Qatar and Abu Dhabi, dated 20 March $1969^{25}$. The Agreement provides that the al-Bunduq field ("Hagl Elbundug") shall be "equally shared" by the parties, and the Parties shall from time to time consult each other on all matters pertaining to this field in order to exercise all the rights on an equal basis. The field is to be developed by the Abu Dhabi Marine Areas (ADMA) Company in accordance with the terms

18. See supra n. 4.

19. See supra n. 5.

20. Ibid., Arts. 1, 4, and 7.

21. Agreement between the State of Kuwait and the Kingdom of Saudi Arabia relating to Partition of the Neutral Zone, 7 July 1965, 6 Energy (1981) pp. 1330-1334; CHURCHILL et al., op. cit. n. 1, p. 212.

22. See W. T. ONORATO, A Case Study in Joint Development: The Saudi Arabia-Kuwait Partitioned Neutral Zone, 10 Energy (1985) p. 540.

23. See supra, n. 21, Arts. 1-4.

24. Ibid., Art. 8.

25. Agreement on Settlement of Maritime Boundary Lines and Sovereignty Rights over Islands between Qatar and Abu Dhabi, 30 March 1969, ST/LEG/SER.B/16, p. 403. 
of the concession granted to it by the Ruler of Abu Dhabi, and all royalties, profits and fees are to be equally divided between the two Governments ${ }^{26}$.

(6) Memorandum of Understanding between Iran and Sharjah, dated 18 November 1971, concerning their overlapping claims to the island of Abu Musa ${ }^{27}$. The two States agreed that exploitation of the petroleum resources in the Abu Musa area would be carried out by Buttes Gas and Oil Company and that "half of the governmental oil resources hereafter attributable to the said exploitation shall be paid directly by the Company to Iran and half to Sharjah"28.

(7) Convention between the Government of the French Republic and the Government of the Spanish State on the Delimitation of the Continental Shelf of the Two States in the Bay of Biscay, dated 29 January $1974^{29}$. The Convention establishes a rectangular special zone for common development, which extends on both sides of their continental shelf boundary. Each party is to exercise sovereign rights over the mineral resources in the zone on its side of the dividing line. However, in an annex to the Convention, the Parties agree to share equally in the resources of the whole zone and to undertake to guarantee interested companies of both parties participation on an equal footing in the exploitation of the mineral resources of the zone $\mathrm{e}^{30}$.

(8) Agreement between Japan and the Republic of Korea concerning Joint Development of the Southern Part of the Continental Shelf adjacent to the Two Countries, dated 5 February $1974^{31}$. The Agreement establishes a joint development zone which may be divided into nine subzones, each of which is to be explored and exploited by concessionaires of both parties in accordance with operating agreements. The concessionaires of both parties share equally the natural resources extracted from the joint development zone, as well as the expenses of exploration and exploitation ${ }^{32}$. The agreement also sets up a Japan-Republic of Korea Joint Committee as

26. Ibid., Arts 6 and 7.

27. Memorandum of Understanding between Iran and Sharjah, November 1971, Middle East Economic Survey, Vol. 15, No. 28 (1972), Supplement.

28. Ibid.

29. Convention entre le Gouvernement de la République Française et le Gouvernement de l'Etat Espagnol sur la Délimitation des Plateaux Continentaux des deux Etats dans le Golfe de Gascogne (Golfe de Biscaye), 29 Jan. 1974, ST/LEG/SER.B/19, p. 445.

30. Ibid., art. 3, Annex 2.

31. Agreement between Japan and the Republic of Korea concerning Joint Development of the Southern Part of the Continental Shelf Adjacent to the Two Countries, 5 February 1974, Churchill, et al., op.cit. n. 1, Vol. 4 (1975), pp. 117-133.

32. lbid., Arts. 4,5 and 9. 
a mechanism for consultation on matters concerning the implementation of the Agreement ${ }^{33}$.

(9) Agreement between Sudan and Saudi Arabia relating to the Joint Exploitation of the Natural Resources of the Sea-Bed and Sub-soil of the Red Sea in the Common Zone, dated 16 May $1974^{34}$. The Agreement recognizes both States' exclusive sovereign rights over the sea-bed areas adjacent to their coasts to a depth of the superjacent water of one thousand meters. The sea-bed area lying between the two areas so defined is to be treated as a "Common Zone", and "the two Governments have equal sovereign rights in all natural resources of the Common Zone which rights are exclusive to them ${ }^{\text {n35 }}$. The Agreement sets up a Joint Commission consisting of an equal number of representatives from each party to exercise comprehensive functions relating to granting licenses and concessions, supervising exploitation, promulgating the relevant regulations, etc. ${ }^{36}$

(10) Agreement between the Government of the United Kingdom of Great Britain and Northern Ireland and the Government of the Kingdom of Norway relating to the Exploitation of the Frigg Field Reservoir and the Transmission of Gas therefrom to the United Kingdom, dated 10 May $1976^{37}$, concluded pursuant to the British-Norwegian Continental Shelf Delimitation Agreement of $1965^{38}$. The Frigg Field Agreement stipulates that the gas reservoir is to be exploited as a "single unit" by means of installations through a "unit operator" appointed by agreement between the licensees of both States, subject to the approval of the two Governments. The Governments jointly determine the position of each installation in relation to the boundary line, and consult with a view of agreeing a determination of the limits and estimated total reserves as well as the apportionment of the reserves of the Frigg Field Reservoir. Exploitation by licensees does not affect each State's jurisdiction over the continental shelf on its side of the boundary ${ }^{39}$.

(11) Memorandum of Understanding between the Kingdom of Thailand and Malaysia on the Establishment of a Joint Authority for the Exploitation

\section{Ibid., Art. 2.}

34. Agreement between Sudan and Saudi Arabia relating to the Joint Exploitation of the Natural Resources of the Sea-Bed and Sub-soil of the Red Sea in the Common Zone, 16 May 1974, ST/LEG/SER.B/18 pp. $452-455$.

35. Ibid., Arts. 3, 4 and 5.

36. Ibid., Arts. 7-14.

37. Agreement between the Government of the United Kingdom of Great Britain and Northern Ireland and the Government of the Kingdom of Norway relating to the Exploitation of the Frigg Field Reservoir and the Transmission of gas therefrom to the United Kingdom, 10 May 1976,6 Energy (1981) pp. 1317-1324.

38. See supra n. 9.

39. See supra n. 37, Arts. 1, 2, 5 and 29. 
of the Resources in the Sea-Bed in a Defined Area of the Continental Shelf of the Two Countries in the Gulf of Thailand, dated 21 February $1979^{40}$. The parties recognize the existence of an overlapping area in the Gulf of Thailand, consider that it is in the best interests of the two countries to exploit the resources of the sea-bed in the overlapping area jointly through mutual co-operation, and establish a Joint Authority which will assume all rights and responsibilities on behalf of both for the exploration and exploitation of non-living resources in the overlapping areas ${ }^{41}$.

(12) Agreement on the Continental Shelf between Iceland and Jan Mayen, dated 22 October $1981^{42}$, concluded between Iceland and Norway on the basis of recommendations made by a Conciliation Commission ${ }^{43}$. Both parties agree to establish a joint development zone which is divided into a Norwegian sector north of the boundary and a smaller Icelandic sector south of the boundary. Each State Party is to apply its legislation and petroleum policy to the sector under its jurisdiction, while exploration and production in the joint development zone is to be based on joint venture contracts ${ }^{44}$.

(13) Aden Agreement between the Yemen Arab Republic and the People's Democratic Republic of Yemen, dated 19 November $1988^{45}$. The Agreement provides for joint investment in the exploration and joint development of the potential hydrocarbon resources of a "Common Region" through the medium of a jointly owned Corporation ${ }^{46}$.

(14) Treaty on the Zone of Co-operation in an Area between the Indonesian Province of East Timor and North Australia, concluded between Australia and Indonesia, dated 11 December $1989^{47}$. The Treaty opens a formerly disputed area of the Timor Sea for joint development and profitsharing between the two countries. Without prejudice to any final settlement of the boundary, the Zone of Co-operation is divided into three

40. Memorandum of Understanding between the Kingdom of Thailand and Malaysia on the Establishment of the Resources of the Sea-.Bed in a Defined Area of the Continental Shelf of the Two Countries in the Gulf of Thailand, 21 February 1979, 6 Energy (1981) pp. 1356-1356.

41. Ibid., Preamble and Arts 1 and 3.

42. Agreement on the Continental Shelf between Iceland and Jan Mayen, 22 October 1981, 21 ILM (1982) pp. 1222-1226.

43. Conciliation Commission on the Continental Shelf Area between Iceland and Jan Mayen, Report and Recommendation to the Governments of Iceland and Norway, 20 ILM (1981) pp. 797-842. The Conciliation Commission was established in accordance with Article 9 of the Agreement concerning Fishery and Continental Shelf Questions of 28 May 1980.

44. See supra n. 42, Arts. 1, 2, 3, 5 and 6.

45. Agreement for the Exploitation of [and Investment in] the Joint Area between the Two Sectors of Yemen, 19 November 1988, published in Arabic in the United Yemen; see W. T. ONORATO, "Joint Development in the International Petroleum Sector: the Yemeni Variant", 39 ICLQ (1990), pp. 653-662.

46. Ibid., p. 656.

47. See supra n. 13. 
areas: Area A, where a Joint Authority will control petroleum exploration and exploitation and provide equal sharing of benefits; Area B, where Australia will have the right to make certain notifications as to permits, licences and leases and share with Indonesia a "resource rent tax"; and Area $\mathrm{C}$. where Indonesia will have a corresponding right. Treaty annexes applicable to Area A establish a Petroleum Mining Code, a Model Production Sharing Contract between the Joint Authority and Contractors, and a Taxation Code for the Avoidance of Double Taxation ${ }^{48}$.

(15) Agreement between the Government of Malaysia and the Government of the Kingdom of Thailand on the Constitution and the Other Matters relating to the Establishment of the Malaysia-Thailand Joint Authority, dated 30 May $1990^{49}$. The Agreement is designed to implement the 1979 Memorandum of Understanding between the two countries, and lays down details of legal status and organization, power and functions as well as financial provisions concerning a Joint Authority. The Joint Authority is to have a legal personality, and will formulate policy and exercise control over all exploration and exploitation of the non-living natural resources in the Joint Development Area ${ }^{50}$.

\section{COMMON FEATURES OF STATE PRACTICE}

From this brief overview of State practice, it will be observed that, although joint development, with or without boundary delimitation, is taking place in a variety of regions in the world, each situation has its own peculiarities, and that no fixed pattern has, as yet, emerged. On the other hand, the arrangements concluded do have similar features, which include the following:

(1) Definition or demarcation of an area as the joint development zone. This is of fundamental importance, although the technique by which this is accomplished, varies. Thus, under the Thailand-Malaysia, Japan-South Korea arrangements, the issue of delimitation was shelved, and the areas of overlapping claims were defined as joint development zones ${ }^{51}$. The Joint Development Zone between Iceland and Norway in the Jan Mayen area was defined by geographical co-ordinates, and divided into a Norwe-

48. Ibid., Arts. 2, 3, 4 and annexes B, C and D; see also the Report of the Secretary General, Law of the Sea, A/45/721, 19 November 1990, p. 12.

49. Agreement between the Government of Malaysia and the Government of the Kingdom of Thailand on the Constitution and the other Matters relating to the Establishment of the Malaysia-Thailand Joint Authority, 30 May 1990; see D. ONG, "Thailand/Malaysia: the Joint Development Agreement 1990", Appendix II, 6 IJECL (1990) pp. 64-72.

50. Ibid.

51. See supra n. 40, Art. 1; supra n. 31, Art. 3. 
gian sector of approximately 32,750 square kilometres (70\%) north of the boundary and smaller Icelandic sector of approximately 12,720 square kilometres (30\%) south of the boundary ${ }^{52}$. The Sudanese-Saudi Arabian Agreement having delimited the respective national jurisdictions by reference to a continuous isobath, designated the deeper area beyond it as the "common zone ${ }^{n 3}$. The Zone of Co-operation between Australia and Indonesia is divided into three areas, A, B and C by geographical co-ordinates, each of which has a separate exploration and exploitation regime applicable to it, and the central and largest area, Area A, being designated an area for joint development ${ }^{54}$.

(2) Apportionment of jurisdiction. Generally, each State party exercises its jurisdiction and applies its laws on its side of a defined boundary within the joint development zone. Thus, the limits of jurisdiction are clearly defined in the Kuwait-Saudi Arabia ${ }^{55}$, Iceland-Norway ${ }^{56}$ and JapanSouth Korea ${ }^{57}$ agreements. Under the Thailand-Malaysia agreement, the two countries divide the joint development zone into a Malaysian subzone and a Thai subzone for the exercise of criminal jurisdiction, whereas the agreement is silent as to the application of administrative and civil laws. The jurisdiction, laws and regulations of either Party pertaining to fishing, navigation, marine pollution, and similar matters in the joint development zone are not affected by the agreement ${ }^{58}$.

(3) Choice of development arrangement. In embarking upon joint development, the States concerned must take into account possible differences in their laws, as well as in their contract, finance and customs regulations and practices. Thailand and Malaysia agree to use a system of production sharing in their joint development area ${ }^{59}$. The Japan-South Korea agreement uses the term "concessionaire ${ }^{n 60}$, and the Kuwait-Saudi Arabia agreement chooses an oil concession system ${ }^{61}$, while joint development between Iceland and Norway takes place on the basis of a jointventure contract ${ }^{62}$. Australia and Indonesia have devised a complete, interlocking contractual and fiscal framework to govern joint develop-

52. See supra n. 42, Arts 2, 5 and 6.

53. See supra n. 34, Art. 5.

54. See supra n. 13, Arts. 2, 3, 4 and Annex A.

55. See supra n. 21, Art. 3.

56. See supra n. 42, Arts. 5 and 6.

57. See supra n. 31, Arts. 7, 8, 16 and 19.

58. See supra n. 40, Arts. 5 and 6, para. 1.

59. Ibid.; see supra n. 49, Art. 8.

60. See supra n. 31, Art. 3

61. See supra n. 21, Art. 9.

62. See supra n. 42, Arts. 4, 5 and 6. 
ment in a central joint development zone, Area A. According to the treaty, a Petroleum Mining Code governs operational activities relating to exploration and exploitation of the petroleum resources in that Zone. A Model Production Sharing Contract provides the format to be used in all production sharing contracts in the Zone, and a Taxation Code spells out provisions for the avoidance of double taxation in respect of activities connected with the Zone ${ }^{63}$.

(4) Establishment of organs and scope of their authority. Generally, joint development agreements create a joint commission or authority based on equal participation, either with broad legal capacity enabling it to enter into agreements with foreign companies, to issue licences and to stipulate terms and exemptions; or a body with limited technical functions, and the power only to co-ordinate activities. Methods of constituting these organs vary, as do their powers. Thailand and Malaysia, by a Memorandum of Understanding in 1979, established a Joint Authority consisting of two chairmen and equal numbers of members from each country, and invested it with "all rights and responsibilities on behalf of both parties for the exploration and exploitation of the non-living natural resources of the sea-bed and sub-soil in the overlapping areas and also for the development, control, and administration of the joint development area"64. The 1990 Agreement between Malaysia and Thailand on the Constitution and Other Matters relating to the Establishment of the Malaysia-Thailand Joint Authority, which is designed to implement the Memorandum of Understanding, specifies that the Joint Authority "shall have a juristic personality" and "shall control all exploration and exploitation of the nonliving natural resources in the Joint Development Area and shall be responsible for the formulation of policies for the same"65. By contrast, the Japan-Republic of Korea Joint Commission and the Kuwait-Saudi Arabia Joint Permanent Committee are to serve only as liaison or consultative organs ${ }^{66}$. The Timor Gap Treaty between Australia and Indonesia creates two bodies charged with the duty of exercising both parties' rights and responsibilities: (1) a Ministerial Council composed of an equal number of ministers from each State, with the responsibility of overall control of petroleum activities in the joint development Zone; and (2) a Joint Authority, responsible to the Ministerial Council, endowed with legal personality and capacity under the laws of each Contracting State,

63. See supra n. 13, annexes B, C, and D. See also W. T. ONORATO, et al, "International Co-operation for Petroleum Development: The Timor Gap Treaty", 5 ICSID Review-Foreign Investment Law Journal (1991) pp. 9-12.

64. See supra n. 40 , Art. 5 , para. 2.

65. See supra n. 49 , Arts. 1 and 7.

66. See supra n. 31, Arts. 14 and 15; supra n. 21, Arts. 17, 18 and 19. 
and charged with the day to day administration and management of petroleum operations in the Zone. The Joint Authority comprises four "Directorates" dealing respectively with technology, finance, legal affairs and corporate services, each of which will be responsible to a group of Executive Directors appointed by the Ministerial Council and consisting of equal numbers of representatives of Australia and Indonesia ${ }^{67}$.

(5) Duration and Termination. Joint development arrangements generally stipulate a period of operation, reflecting the Parties' political expectations, as well as the limits of economic and technological forecasting. Thus, the agreement between Thailand and Malaysia is for a period of 50 years, and is to remain in force even after the expiry of the 50 year period, unless the State Parties have delimited the continental shelf in the area of overlapping claims before expiry of the period ${ }^{68}$. The agreement between Japan and South Korea was concluded also for a period of 50 years, but is to continue in force thereafter if it is not terminated ${ }^{69}$. The Timor Gap Treaty between Australia and Indonesia is to operate for an initial period of 40 years from its entry into force, and thereafter for further periods of 20 years unless the Contracting States agree otherwise ${ }^{70}$.

(6) Settlement of disputes. While dispute settlement is generally provided for, there is no uniformity or preference for a particular method. Thus, the agreement between Iceland and Norway, for example, provides for conciliation ${ }^{71}$, whereas some other agreements call for binding dispute settlement ${ }^{72}$.

\section{RELEVANT PROVISIONS OF THE 1982 UNITED NATIONS CONVENTION ON THE LAW OF THE SEA}

The 1982 United Nations Convention on the Law of the Sea makes little express provision regarding the exploration and exploitation of natural resources which extend across a boundary or lie in an area subject to overlapping claims. However, four features of the Convention offer guidance, if not explicit direction, in resolving the issues associated with joint development of resources. They call for application of the principle of co-

67. See supra n.13, Arts. 5-11. See also G. J. MOLONEY, "Australia-Indonesia Timor Gap Zone of Co-operation Treaty: A New Offshore Petroleum Regime», 8 JENRL (1990) p. 136; W. T. ONORATO, supra n. 63.

68. See supra n. 40, Art. 3, para. 1 and 6.

69. See supra n. 31, Art. 31.

70. See supra n. 13, Art. 33.

71. See supra n. 42, Art. 9.

72. E.g., Saudi Arabia-Kuwait Treaty, Art. 22; Frigg Field Treaty, Art. 28. 
operation as reflected in such conduct as consultation, notification, cooperation and agreement. Thus, the Convention, recognizing the marine environment as a shared resource which must be protected and preserved by all States (article 197), goes on to require preventive (protective) action by States (articles 194-5) and to call for global and regional co-operation in the formulation of international rules to that end, as well as to specify the conduct (notification, co-operation) required of a State which becomes aware of immediate threat of damages to the marine environment (articles 198-9). A second feature relates to living resources which occur within the exclusive economic zones of two or more coastal States, or both within the exclusive economic zone and in an area beyond and adjacent to - the so-called "straddling stocks" (article 63). Here States are directed to reach agreement upon "measures necessary to coordinate and ensure the conservation and development of such stocks" or, when the stocks traverse an adjacent area beyond an exclusive economic zone, to seek directly or through appropriate sub-regional or regional organizations to agree upon the "measures necessary for the conservation of these stocks in the adjacent area".

The third and fourth features of the Convention relevant to the merging concept of joint development deal directly with mineral resources, viz. articles 74 and 83 , drafted in identical terms, concerning delimitation of exclusive economic zones and continental shelves respectively; and article 142 on resource deposits which extend from an exclusive economic zone into the international sea-bed "Area".

Article 74 on exclusive economic zone delimitation (identical in form with article 83 on continental shelf delimitation) in paragraph 1 directs the States concerned to effect delimitation "by agreement on the basis of international law", requiring also that:

"3. Pending agreement as provided for in paragraph 1, the States concerned, in a spirit of understanding and co-operation, shall make every effort to enter into provisional arrangements of a practical nature and, during this transitional period, not to jeopardize or hamper the reaching of the final agreement. Such arrangements shall be without prejudice to the final delimitation."

The States concerned are thus under an obligation in the first instance to enter into negotiations with a view to concluding an agreement, and pending agreement, to enter into provisional arrangements governing the area in question during a transitional period which would terminate upon conclusion of a delimitation agreement. While the obligation to negotiate is clear, the outcome of such negotiations cannot be foreseen. Accordingly, the States concerned are directed (1) "if no agreement can be reached within a reasonable period of time..." to have recourse to the 
Convention's dispute settlement procedures; and (2) in any event, until agreement is reached, to "enter into provisional arrangements" of the type specified in the third paragraph of both articles. Dispute settlement would, however, be necessary only if a dispute has actually arisen, or persists. If, on the other hand, a dispute over delimitation could be avoided, or an existing territorial dispute laid aside while the parties decide instead to grasp the benefits of co-operative exploitation of an area subject to concurrent claims, the resulting "provisional arrangement" could be embodied in an agreement which, although not dealing with delimitation as such, would satisfy the letter and spirit, as well as the aims, of articles 74 and 83. This may be implied from the final paragraph of articles 74/83:

"4. Where there is an agreement in force between the States concerned, questions relating to the delimitation of the [exclusive economic zone] [continental shelf] shall be determined in accordance with the provisions of that agreement."

The provision is thus broad enough to comprehend situations in which the parties have decided to postpone delimitation questions, or lay them aside altogether.

Article 142 of the Convention deals with resource deposits lying across the boundary between an area subject to a coastal State's jurisdiction, and "the Area" subject to the jurisdiction of the International SeaBed Authority to be established under the Convention. Assuming the State's boundary to be dealt with in consultation with the Commission on the Limits of the Continental Shelf, the article does not address delimitation issues, but instead offers an outline of the basic principles and procedures applicable in such circumstances, when exploitation of the "straddling" resource is contemplated. These principles and procedures could well serve as the basis for a regime of joint development between the coastal State and the Authority, and indeed, between two or more coastal States:

"Article 142

1. Activities in the Area, with respect to resource deposits in the Area which lie across limits of national jurisdiction, shall be conducted with due regard to the rights and legitimate interests of any coastal State across whose jurisdiction such deposits lie.

2. Consultation, including a system of prior notification shall be maintained with the State concerned, with a view to avoiding infringement of such rights and interests. In cases where activities in the Area may result in the exploitation of resources lying within national jurisdiction, the prior consent of the coastal State concerned shall be required. 
3. "

Article 142, no less than paragraph 3 of articles 74 and 83 , seems to be derived from a solid basis in State practice followed with regard to oilbearing structures lying across national boundaries. The first clause embodying that practice occurs in the 1965 agreement between the United Kingdom and Norway delimiting their continental shelves in the North Sea:

\section{"Article 4}

If any single geological petroleum structure or petroleum field, or any single geological structure or field of any other mineral deposit, including sand or gravel, extends across the dividing line and the part of such structure of field which is situated on one side of the dividing line is exploitable, wholly or in part, from the other side of the dividing line, the Contracting Parties shall, in agreement with the licensees, if any, seek to reach agreement as to the manner in which the structure or field shall be most effectively exploited and the manner in which the proceeds deriving therefrom shall be apportioned."

Similar clauses have since been included in a wide range of delimitation agreements ${ }^{73}$ and joint development agreements ${ }^{74}$.

\section{EMERGING FEATURES OF JOINT DEVELOPMENT}

Although we have no reason to conclude that the provisions of articles 74,83 , and 142 of the 1982 United Nations Convention on the Law of the Sea were drafted with a view to encouraging arrangements for joint development of the type here considered, read together they provide such arrangements with an authoritative basis in principle with the following parameters:

73. Norway-United Kingdom, 1965; Netherlands-United Kingdom, 1965; Denmark-Norway, 1965; United Kingdom-Denmark, 1966; Norway-Sweden, 1968; Italy-Yugoslavia, 1968; Indonesia-Malaysia, 1969; Iran-Qatar, 1969; Iran-Bahrain, 1971; F. R. of Germany-Denmark, 1971; F. R. of Germany-Netherlands, 1971; F. R. of Germany-United Kingdom, 1971; United Kingdom-Denmark, 1971; Italy-Tunisia, 1971; Indonesia-Thailand, 1971; Denmark-United Kingdom, 1971; Australia-Indonesia, 1971; Sweden-Finland, 1972; Denmark-Canada, 1973; Iran-United Arab Emirates, 1974; Indonesia-Malaysia-Thailand, 1974; India-Sri Lanka, 1974; India-Indonesia, 1974; Italy-Spain, 1974; Sudan-Saudi Arabia, 1974; India-Sri Lanka-Maldives, 1976; Greece-Italy, 1977; Thailand-India, 1978; Thailand-Malaysia, 1978; Venezuela-Netherlands, 1978; D. R. of Germany-Sweden, 1978; Thailand-Malaysia, 1979; Denmark-Norway, 1979; Iceland-Norway, 1981; Sweden-Denmark, 1984; Colombia-Honduras, 1986; Solomon-Australia, 1988; United Kingdom-Ireland, 1988.

74. France-Spain, 1974, art. 4 para. 2; Japan-South Korea, 1971, Art. 23; Sudan-Saudi Arabia, 1974, Art. 14; Thailand-Malaysia, 1979, Art. 3, para. 6; Iceland-Norway, 1981, Art. 8. 
(1) use or exploitation of a resource on one side of a national boundary must take account of rights and legitimate interests of the State on the other side of the boundary, implying obligations of a co-operative character such as accommodation of uses, and equitable apportionment of resources (art. 142(1));

(2) where activities on one side of a national boundary would result in exploitation of resources on the other side of such a boundary, mutual consent is required (art. 142(2));

(3) prior notification and consultation are prescribed as the means for ascertaining mutual consent (art. 142(2));

(4) the solution arrived at (whether or not accompanied by actual delimitation) must be equitable (art. 74/83(1) and (3));

(5) mutual consent is to be recorded in a written agreement (art. 74/ 83(1));

(6) the agreement must have a basis in international law (art. 74/ 83(1));

(7) the Parties are obliged, pending conclusion of an agreement, to enter into "provisional arrangements of a practical nature and... not to jeopardize or hamper the reaching of the final agreement....", implying establishment of a dynamic, use-oriented and mutually beneficial regime which, since the issue of delimitation is not addressed, could well mature into a system of joint exploitation if managed in "a spirit of understanding and co-operation", i.e., in good faith;

(8) the agreement should generally,

(a) demarcate the joint development zone by geographical co-ordinates and other appropriate points of reference;

(b) apportion jurisdiction among the States concerned;

(c) lay down the basic system to be followed, e.g., production-sharing, profit-sharing;

(d) establish one or more supervisory organs with proportionate representation and appropriate provisions on decision-making;

(e) state its duration and/or procedure for renewal;

(f) provide for the settlement of disputes.

Have some or all of these features become part of customary international law? We may recall here, that referring to the emergence of customary law, the International Court of Justice in the 1969 North Sea Continental Shelf Cases observed that:

"... an indispensable requirement would be that within the period in question, short though it might be, State practice, including that of States whose interests are specially affected, should have been both extensive and virtually uniform in the sense of the provision involved, and should 
moreover have occurred in such a way as to show a general recognition that a rule of law or legal obligation is involved" 75 .

As has been noted above, State practice concerning joint development has existed for over 30 years: some 13 Asian, 9 European, 1 African, and 1 Australian States are current parties to joint development agreements. Evidence of the emergence of an opinio juris among the generality of States may also be derived from the broad support attracted to the text of the 1982 United Nations Convention on the Law of the Sea, and particularly articles 74,83 and 142, in respect of which acceptance may be said to be unanimous, and to have remained uncontroverted in the years since formal adoption of the Convention.

In the opinion of one recent authority:

"There is... a legally binding and practically implementable regime of law
which governs the apportionment of international common petroleum
deposits among interested States... The practice of negotiation and seeking
agreement on the exploitation and apportionment of a common deposit is
not mere usage but, rather, a current customary rule of international
law"76.

Another disagrees, observing that "what might be reasonable and obligatory in one part of the world might not necessarily be considered so in other parts with different conceptions of lawn77, questioning the validity of a purely objective appraisal in determining the existence of a customary rule, and doubting whether it would be "admissible in customary international law to compel interested States to co-operate for joint development when they are not disposed to it for some reasons" ${ }^{78}$.

While conceding that it might be premature to conclude that State practice regarding joint development with respect to certain "straddling" resources has matured into rules of customary international law, the trend in that direction emerging, principally as it happens among Asian States, seems clear. In this connection we may recall the dictum of Judge Tanaka in his dissenting opinion in the 1969 North Sea Continental Shelf Cases favouring an objective mode of determining the emergence of customary rules, when he observed that there was

"no other way than to ascertain the existence of opinio juris from the fact of the external existence of a certain custom and its necessity felt in the inter-

75. [1969] ICJ Rep. para. 74; 8 ILM (1969) p. 375.

76. W. T ONORATO, “Joint Development of Sea-Bed Hydrocarbon Resources: An Overview of Precedents in the North Sea", 6 Energy (1981) p. 1315.

77. M. MIYOSHI, "The Basic Concept of Joint Development of Hydrocarbon Resources on the Continental Shelf", Appendix II, 3 IJECL (1988) p. 9.

78. Ibid. p. 10. 
national community rather than to seek evidence as to the subjective motives for each example of State practice" ${ }^{\text {79. }}$.

\section{CHINA AND JOINT DEVELOPMENT}

China has a continental coastline of some 18,000 kilometres, and about 6,000 islands with a total area of 80,000 square kilometres scattered in the Bo Hai (an internal sea), the Yellow Sea, the East China Sea and the South China Sea. These marine areas are rich in natural resources, both living and non-living, and are of vital importance to China both for its economic development and national security. Committed to a programme of modernization, China currently lacks the energy resources needed for its implementation. However, China's onshore and offshore oil potential is considerable. Some one million square kilometres of China's continental shelf area in the Bo Hai, Yellow Sea, East China Sea and South China Sea are believed to contain rich oil and gas deposits and may together comprise one of the largest oil bearing areas of the world ${ }^{80}$. Moreover, these offshore areas are close to domestic industrial centres, so that exploitation and transport of oil for domestic use and export would be relatively easy. Given China's economic objectives and strategic interests, it is hardly surprising that offshore energy resource development became an important element in its modernization strategy.

However, the discovery of rich petroleum deposits offshore during the late 1970s and early 1980s led the coastal States of the Yellow and East China Sea and the South China Sea to declare 200 mile exclusive economic zones, fishery zones or continental shelves ${ }^{81}$. Many areas thus became subject to overlapping claims by two or more countries, in some instances accompanied by active occupation ${ }^{82}$, raising political tensions in the region.

79. [1969] ICJ Rep. Dissenting Opinion of Judge TANAKA; 8 ILM (1969) p. 408.

80. See P. C. YUAN, "China's Offshore Oil Development Policy and Legislation: An Overall Analysis ${ }^{n}, 3$ IJECL (1988) p. 108. Estimates of the oil resources in China's offshore area vary greatly, but both Chinese and foreign sources unanimously agree that there are good prospects for oil exploitation in China's offshore.

81. In 1977, Vietnam made a statement on its territorial sea, contiguous zone, continental shelf and exclusive economic zone. North Korea declared to establish a 200-mile EEZ. South Korea promulgated a law for the development of submarine mineral resources. In 1979, Japan proclaimed a 200-mile fishery zone. In 1980, Indonesia and Malaysia proclaimed their rights to a 200-mile EEZs respectively.

82. Vietnam, the Philippines and Malaysia have occupied some islands of the Nan Sha (Spratly) Archipelago. For details, see C. Lo, China's Policy towards Territorial Disputes (Routledge, 1989). 
From China's perspective, the main problems concern its claim to territorial sovereignty over the Diao Yu Dai Islands (Senkaku in Japanese) in the East China Sea, and the Xi Sha (Paracel) and Nan Sha (Spratly) islands in the South China Sea; the identification of its economic zone and continental shelf; and the settlement of disputes over demarcation of maritime boundaries among all the claimants. The complex historical bases of the claims, the importance of oil and gas to the claimants, and their national security interests, as well as the involvement of powers from outside the region, make it unlikely that formal settlement of territorial and maritime boundaries could be reached in the short term. China, in search of an alternative approach, may be willing to endorse the concept of "joint development".

Under China's new "open door" policy for economic development, which has removed political barriers to China's acceptance of co-operation with foreign capital and technologies in developing its offshore oil resources, joint development of disputed sea areas with foreign co-operation is no longer regarded per se as infringement of China's sovereignty and an unacceptable diversion of China's resources into foreign hands. On 10 February 1982, China promulgated Regulations of the People's Republic of China on the Exploitation of Offshore Petroleum Resources in Co-operation with Foreign Enterprises, the first ocean mineral law to be enacted since the establishment of the People's Republic of China in 1949. The Regulations establish a broad framework of principles and guidelines governing petroleum exploitation in offshore areas and co-operation with foreign entities in such operations. The strategic measures adopted by the China National Offshore Oil Corporation include provisions on encouragement of foreign collaboration, and opening the East China Sea to development by foreign contractors ${ }^{83}$.

The concept of "joint development" seems to have received the endorsement of DENG XIAOPING himself. During a press conference in Tokyo in 1978, on the prospects for settling the dispute on the Diao Yu Dai Islands DENG said that:

\footnotetext{
"It is true that the two sides maintain different views on this question... It does not matter if this question is shelved for some time, say, ten years. Our generation is not wise enough to find common language on this question. Our next generation will certainly be wiser. They will certainly find a solution acceptable to all"84.
}

83. The five strategic measures are: 1 . Sticking to and developing foreign co-operation; 2 . Continuously developing China's independently managed prospecting and exploitation; 3 . Building a natural gas production base in the western part of the South China Sea; 4 . Opening the East China Sea to the outside world; 5 . Building oil refining and petrochemical industries.

Beijing Review, 10-16 July 9 1982, p. 29. 
In 1984, during a meeting with a delegation from the West, DENG spoke about the new approach to territorial disputes:

"I have also considered the possibility of resolving certain territorial disputes by having the countries concerned jointly develop the disputed areas before discussing the question of sovereignty. A new approach should be sought to solve such problems according to realities"85.

Later, in October 1984, at the Third Plenary Session of the Central Advisory Committee of the Communist Party of China, DENG mentioned the idea again:

"International disputes that are not handled right can reach the flash point.
I asked them (foreign guests) whether the policy of 'one country, two sys-
tems' could be adopted in some cases and the policy of 'joint development'
in others... We Chinese stand for peace and hope to solve disputes by
peaceful means. What kind of peaceful means? 'One country, two systems'
and 'joint development'. Everyone says this is a new and very interesting
idea" 66 .

\section{The East China Sea}

Since the 1970s, the idea of "joint development" has attracted the attention of the countries in this region. Following a report of high probability of rich oil resources in the Yellow and the East China Seas ${ }^{87}$, Japan, South Korea and Taiwan began protracted negotiations over claims to their continental shelves, presumably ignoring China's historic claim. In 1970 , the parties agreed in principle to set up a joint development project, but following strong protest by China, the scheme was abandoned two years later ${ }^{88}$. Undeterred by this failure, Japan and South Korea resumed negotiations in late 1972, and this time, spurred by the oil crisis of 1973 , went on to conclude a joint development agreement in February $1974^{89}$. As noted above, this agreement divided a specified joint development, and established a joint commission to carry out various functions therein. South Korea ratified the agreement in December 1974, but

84. Peking Review, 3 November 1978, p. 16.

85. DENG XIAOPING, Build Socialism with Chinese Characteristics (Beijing: Foreign Language Press, 1985), p. 24.

86. Ibid., p. 56.

87. EMERY, et al., "Geological Structure and some Water Characteristics of the East China Sea and the Yellow Sea", 2 ECAFE/CCOP Technical Bulletin (1969) p. 41; see also D. M. H. Johnston, et al., Ocean Boundary Making: Regional Issues and Development (Croom Helm, 1988) p. 91.

88. JOHNSTON, op. cit. n. 87, p. 82.

89. See supra n. 31. 
approval by Japan took four and a half years. Exploration operations began in mid-1979, but thus far no commercial quantities of oil have been discovered ${ }^{90}$. China's response to the joint development, was to declare promptly:

\begin{abstract}
"To one-sidedly mark off a large area of the continental shelf as a so-called 'joint development zone' behind China's back is an infringement on China's sovereignty... anyone who arbitrarily carries out development activities in this area must bear full responsibility for all the consequences arising therefrom" ${ }^{\prime \prime 1}$.
\end{abstract}

While China remains opposed to the Japan-South Korea arrangement because of continental shelf delimitation problems ${ }^{92}$, China's approach to the concept of joint development itself was positive. Thus, having launched exploration and exploitation of oil and gas resources with foreign co-operation in offshore areas such as Bo Hai and Ying Ge Hai, China has cautiously turned to consideration of the possibility of joint development with Japan in the disputed East China Sea. In September 1979, during a visit to Tokyo, China's Vice-Premier, Gu MU, suggested that the dispute over the Diao Yu Dai should be shelved while the two countries undertook joint development of oil resources in the surrounding sea areas $^{93}$. The Japanese Government responded positively to the idea ${ }^{94}$. In December 1980, a meeting at expert level between China and Japan took place in Beijing, the Chinese side advocating the creation of joint development zones in the area of overlapping claims. The proposal was taken back to Tokyo for consideration, but evidently evoked no response ${ }^{95}$. In October 1982, China's Vice-Premier, YAO YILIN, expressed the view that it might be desirable to invite the United States to participate in such a joint development project as well as Japan ${ }^{96}$.

Recently, China and Japan resumed negotiations on joint development in the East China Sea at the level of the oil industries of the two countries. Two problems must be resolved before there can be agreement on the matter. The first of them concerns sovereignty over the Diao Yu Dai Islands. China prefers issues of sovereignty to be shelved in order to permit oil exploration to proceed, while Japan, with the Islands under its

90. JOHNSTON, op.cit. supra n. 87, p. 92; see also M. MIYOSHI, "The Japan-South Korea Agreement on Joint Development of the Continental Shelf", 10 Energy (1985) p. 551.

91. Peking Review, 12 April 1974, p. 7.

92. E.g., see Peking Review, 8 February 1974, p. 3; 17 June 1976, pp. 16-17; 26 June 1978, p. 25.

93. C. Lo, op.cit. supra n. 82, p. 172.

94. Ibid., pp. 172-173.

95. See M. J. VALENCIA, "Northeast Asia: Petroleum Potential, Jurisdictional Claims, and International Relations", 20 ODIL (1989), p. 53.

96. JOHNSTON, op.cit. supra n. 87, p. 101. 
physical control, is reluctant to admit any doubt as to its sovereignty claim.

The second problem is that of selecting and demarcating the joint development zone. China suggests confining the joint development zone to the area of overlapping claims, while Japan would like to establish the zone across the median-line and into the Chinese side beyond the area of overlap $^{97}$. As one commentator points out,

"for the idea of joint development to be successful, the gap between overlapping claims to maritime space should not be too wide, otherwise both sides to the dispute might feel that they would have to make too great a compromise" 98 .

The difficulty of negotiating a joint development arrangement is compounded by the fact that in the East China Sea, China claims sovereignty over its continental shelf based on the principle of "natural prolongation", while Japan insists on the median line approach. If joint development were to be limited to an area of the continental shelf on either side of a median line, China might be seen implicitly to accept the Japanese approach, thus adversely affecting China's position in any final settlement of the boundary delimitation question. However, as neither side seems willing to yield on the question of sovereignty over the Diao Yu Dai Islands, and the surrounding area has good prospects for oil production, to shelve the question and conclude a joint development arrangement with Japan could offer a sound practical solution.

The recent signing of the Timor Gap Treaty between Australia and Indonesia could well encourage the emergence of such a solution, through demonstrating the feasibility of joint development under the geological conditions prevailing in East Timor between Australia and Indonesia, which closely resemble the geology in the East China Sea ${ }^{99}$. Both the negotiation and the operation of the Timor Gap agreement could provide China and Japan with valuable experience and precedent. Since oil is of critical importance to both countries' economies, and given their successful co-operation in the Bo Hai and the Yellow Sea, there is every likelihood that negotiations over joint development in the East China Sea will lead eventually to agreement.

97. See also ZHIGUO GAO, Joint Development of Overlapping Continental Shelf Areas in International Law - with Special Reference to Joint Development in the East China Sea (occasional paper, 1990) p. 37.

98. C. LO, op.cit. supra n. 82, pp. 173-174.

99. See K. F. ROYER, "Japan's East China Sea Ocean Boundaries: What Solutions can a Confused Legal Environment Provide in a Complex Boundary Dispute?", 22 Vanderbilt JTL (1989) pp. $522-630$. 


\section{The South China Sea}

In the South China Sea as well, the question of access to the area's mineral resources is complicated by territorial disputes involving several countries. Proposals for joint development in the South China Sea are being considered by China, and the attitude of the Chinese leadership could also be positive. DENG'S remarks concerning the East China Sea could be seen as the expression of a general policy applicable also in respect of the South China Sea. Thus DENG has suggested to the Philippine Government the idea of shelving sovereignty disputes and, instead, establishing a joint development arrangement for oil exploitation in the Nan Sha Islands. Such a scheme finds endorsement in the writings of experts in the field. MARK VALENCIA, for example, has observed:

"Perhaps one of the best candidates for joint development would be por-
tions of the Spratly [Nan Sha] area. If Vietnam and the Chinese province of
Taiwan could somehow be excluded from the Spratly issues, China, the
Philippines and Malaysia could undertake joint exploration there, perhaps
in areas farthest from Vietnamese claimed islands"100.

However, much preparatory work remains to be done before China takes a final position on proposals for joint development in the South China Sea. First, China must clearly identify its own maritime space in the sub-region. In order to do so, China would have to overcome difficulties similar to those which it faced in the dispute with Japan over Diao Yu Dao Islands and the continental shelf boundary delimitation in the East China Sea. Second, China has remained consistent and firm in its assertion of sovereignty over the Xi Sha (Paracel) and Nan Sha (Spratly) Islands, in respect of which Vietnam, the Philippines and Malaysia have not only put forward sovereignty claims, but also followed strategies of establishing and maintaining physical presence. Although China's recent establishment of a marine scientific survey station on one of the Nan Sha Islands in 1988 demonstrated its determination to exercise sovereignty and the capacity to defend its claims, it has yet to maintain a permanent physical presence on the Islands generally, and thus strengthen its position in any negotiation over joint development of their resources. It seems safe to conclude that, given the legal complexities arising out of conflicting claims, the movement toward joint development is likely to progress more slowly in relation to the resources of the South China Sea than of the East China Sea.

100. M. J. VALENCIA, et al., Marine Policy, p. 187, as cited in C. Lo, supra n. 82., p. 175. 


\section{CONCLUSION}

"Joint development", or co-operative exploration, exploitation and management of off-shore mineral resources pursuant to inter-governmental agreement, seems assured of a place among the strategies of goodneighbourliness which may be used to establish or maintain friendly and mutually beneficial relations among States. Applied with a view to early realization of benefits from mineral wealth which might otherwise be left undeveloped during protracted negotiations concerning the limits of national sovereignties, joint development is representative of a modern trend away from narrow autarkic nationalism, and toward recognition of the benefits of consensus, co-operation and balanced inter-dependence among States. "Joint development" is a pragmatic solution capable of accomplishing the avoidance of confrontation and its wasteful consequences, through focusing on positive approaches and the initiation of productive activity from which tangible benefits accrue to all concerned.

While one need look no further than common sense for the roots of the idea of joint development, conceptual endorsement is to be found in relevant provisions of the United Nations Convention on the Law of the Sea, particularly articles 74 and 83, and article 142 discussed in part 4 above, and in an emerging customary framework discussed in part 5 . In their search for new sources of petroleum and natural gas more coastal States are likely to turn away from sterile jurisdictional controversy, and to consider the practical advantages to be derived from regimes of joint development. Among the marine areas in which such regimes might usefully be applied are those between Vietnam and Kampuchea in the Gulf of Thailand ${ }^{101}$; between the United States and the Soviet Union in the Bering $\mathrm{Sea}^{102}$; between Venezuela and Trinidad and Tobago in the Gulf of Paria ${ }^{103}$; between the United States and Canada in the Beaufort Sea ${ }^{104}$; and between the United Kingdom and Denmark in the North Sea ${ }^{105}$. As one authority has observed:

"In an energy-poor world with many areas of off-shore hydrocarbon potential claimed by more than one desperate country, joint development is an idea whose time is coming" 106 .

101. See M. J. VALENCIA, et al., supra n. 14.

102. See C. M. ANTINORI, "The Bering Sea: A Maritime Delimitation Dispute between the United States and the Soviet Union", 18 ODIL (1987) p. 1.

103. See E. L. RICHARDSON, “Jan Mayen in Perspective”, 82 AJIL (1988) pp. 454-455.

104. Ibid., pp. $456-457$.

105. Ibid. p. 457.

106. M. J. VALENCIA, et al., supra n. 14, p. 247. 
While the present essay does not afford the proper context for a full examination of the cultural aspects of the emerging concept of joint development in international law, it may not be out of place to suggest here that joint development might, for several reasons, be a device of particular interest and appeal to Asian societies. In the first place, Asia as a geographic area is vast, and as a geo-political concept may be said to extend from the shores of the Red Sea eastward across a massive continental landmass and beyond, to encompass even the island States of the Pacific Ocean. The sheer number of maritime boundaries, demarcation of which could needlessly divert the slender resources of the States concerned, is substantial, and the need for imaginative ways to resolve such situations expeditiously, is correspondingly great.

Again, scholars have for centuries observed at the core of Asian cultures an essential need to preserve harmony. Overt expression of that need is seen in conduct directed at consensus-building, as well as in cooperative behaviour governed by rules that emphasize the collectivity rather than the individual. These characteristics may well be found to predispose Asian cultures to accept regimes of joint development, the essence of which is setting conflict aside in favour of co-operative endeavour for mutual benefit. The spirit of joint development may, indeed, be epitomized in an ancient Chinese proverb which runs "Qiu Tong Cun Yi" or "Seek common ground while preserving differences".

Although the earliest agreement mentioned above providing for joint development of mineral resources (albeit land resources) is between European States (Austria and Czechoslovakia) the question of where the modern concept originated is not necessarily of critical significance. The examples quoted in part 2 show convincingly the substantial contribution made to the elaboration of the concept by European States whose cultures emphasize the individual rather than the collectivity, but have achieved, nevertheless, the most complete workable model to-date of regional co-operation and integration. It is nevertheless worth noting that of some 24 States currently parties to joint development arrangements, the majority, 13, are Asian. The acute need of all but a few Asian States to speed economic development, and the cultural core characteristics referred to, are likely to steer these States in the direction of adopting cooperative arrangements with features such as those mentioned in part 5 . With endorsement forthcoming from larger Asian States such as China, Japan and Indonesia, techniques of joint development may well make a major contribution to the well-being of peoples of the region, becoming in time the solution most appropriate as being the most readily internalized among the States concerned. 